\title{
The International Geological Congress of I922.
}

THE publication of the complete "Livret-Guide des Excursions en Belgique" and "Résumés des Communications Annoncées" affords us an opportunity of reviewing the work of the first International Geological Congress which has met since the war.

There are few countries that are so eminently adapted for a geological gathering as Belgium. With the exception of strata of pre-Cambrian age, all the formations are adequately represented within an easy railway journey from the capital. The rocks are well exposed on the sides of the deeply-cut river valleys and in the numerous quarries for limestone and sandstone, which are being actively worked for building material and road metal, and valuable information has been afforded by the coal mines and borings for coal. There has accordingly been every facility for the investigation of the geological structure, which is of the greatest interest. The area was subjected to great movements from the south in connexion with both the "Caledonian" and "Hercynian" epochs of disturbance in the earth's crust. The latter, which took place at the close of the Carboniferous Period, resulted not only in numerous well-marked folds but in extensive thrusts (charriages) from the south which brought older strata over those of younger age, in the same manner as ancient crystalline rocks were forced over Cambrian strata in the north-west highlands of Scotland during the Caledonian movements.

The very full and clear development of Devonian and Carboniferous strata and the careful work of the Belgian geologists upon them render a visit to Belgium peculiarly instructive to students of those formations in this country and throughout the world. The succession, too, of the Tertiary rocks of Belgium is also remarkably complete, and many of our British geologists welcomed the opportunity of familiarising themselves with them.

Nothing could exceed the efficiency with which the congress was organised; and this reflects the greatest credit on M. Armaud Renier, the General Secretary, and his co-workers.

In one respect the congress presented a remarkable contrast to scientific gatherings in this country. Every member was permitted in all his railway journeys in connexion with the congress to travel at half the usual rates, whereas the members of the British Association know to their cost that since the war the railway companies have refused to abate a penny of their fares to those who take part in the annual meetings.

Excursions were carried out before, during, and after the meeting at Brussels. Those before the congress lasted from six to nine days, and comprised traverses from south to north in the east of Belgium (M. Fourmarier) and in the centre (MM. Kaisin, Mailleux, and Asselbergh), and a special study of the metamorphic regions of Veilsalm and Bastogne (M. Lohest) and also of the Tertiary rocks (M. Leriche). The excursions after the congress included studies of the Cretaceous and Tertiary rocks of the neighbourhood of Mons (M. Cornet) and of the Carboniferous strata (MM. Lohest, Kaisin, and Renier), while M. Fourmarier devoted a fortnight to a detailed survey of the remarkable tectonics of the Palæozoic rocks. The "Livret-Guide" to these excursions remains as an invaluable work of reference on the geology of the country.

The formal opening of the congress took place on August Io in the presence of His Majesty the King of the Belgians, and M. Jean Lebacqz was elected president. Two or three sessions were held simultaneously and numerous important papers were read. A large number of these dealt with the character of the Hercynian disturbances in different areas, and they constitute important contributions to the literature of the subject, but much still remains to be done in correlating these movements and determining how far they were contemporaneous or successive in adjoining regions.

A noteworthy feature of the congress was the presence for the first time of representatives from Poland, Czechoslovakia, and Yugoslavia. No invitation was extended to the Central powers, which were on this occasion unrepresented. A proposal, which originated with MM. De Margerie and Lacroix, to prepare an international geological map of Africa, was welcomed by the representatives of the other powers having interests in that continent, and they agreed to co-operate in the undertaking.

It was proposed by Señor Rubio-y-Muñoz, the principal representative of Spain, that the next congress should take place in Madrid, and an attractive programme of excursions was promised. This was unanimously accepted. The question was raised as to whether the congress should continue on the lines which had hitherto been followed or should be transformed into an International Union of Geology affiliated to the International Research Council There was a strong feeling in favour of the former course, and a constitution was adopted which will, it is believed, ensure the preservation of the past traditions of the congress as a great reunion of fellowworkers in geology in which all nations are represented.

\section{Education, Research, and Invention.}

$\mathrm{T}$ is natural to find that a large portion of the presidential address delivered before the Institution of Mechanical Engineers by Prof. H. S. Hele-Shaw on October 20 should deal with education, research, and scientific knowledge and invention, in all of which the president himself has played an important part. The Institution has now before it the results of the first year's work in the examinations for national certificates and diplomas. These examinations are conducted by the technical schools, together with assessors appointed by the Institution, who are responsible for considering all papers and for reviewing and supervising all results. All the results are submitted to a joint committee of the council of the Institution and the Board of Educa- tion, and all border-line cases are specially considered. It is of interest to note that in more than one case the Institution has had to modify the severity of the school, which is far more satisfactory than if technical schools desired to pass their candidates too easily. Of the $125^{\circ}$ candidates drawn from fortyeight technical schools, fifty-one per cent. have been awarded various grades of national certificates and diplomas. The Institution does not appear as yet to be ready to give a decision as to whether these examinations will be accepted in lieu of the Institution's own examinations for associate membership, although the matter appears to be under consideration.

It is now nearly fifty years since the Institution appointed its first research committee; since then 
the sum of between I3,oool. and I4,oool. has been expended in research. There is no doubt that this policy has greatly enhanced the reputation of the Institution and has been of the utmost value to the engineering world. The time has arrived when the relation of the Institution to the National Physical Laboratory and the Government Department of Scientific and Industrial Research must be carefully considered. In view of present-day demands on the Institution and its members in all parts of the world, the council must consider to what extent, if any, it will be able to contribute in future to researches which may well be left in the hands of the abovementioned bodies. The Institution is closely associated with both bodies through several members of council, and these will continue, as in the past, to give freely their services and experience. There is also a feeling that the Institution should not encroach upon the ground which newer and special Institutions are better qualified to undertake.

Prof. Hele-Shaw has long been known for his interest in inventions, and his remarks on inventions and inventors are of value. All progress, at any rate in mechanical science, must be in the nature of invention. Every step taken in which new ground is trodden, every new device or new mechanism, or new machine of changed form, in which the movements of parts differ, or even if the object attained is different, can result only from the exercise of the inventive faculty. If a man cannot do more than alter the dimensions of the machinery which he is constructing, he cannot be called an engineer at all. Even where it is necessary to duplicate indefinitely any existing machine or machine part, invention is required, and has in recent years been exercised in a wonderful way for production purposes.

The present stress of competition necessitates the more intense application of the inventive faculty, and an average of 30,000 patents is taken out each year by inventors searching for new devices and new results. It is easy to see what a hopeless task is being attempted by the ignorant and uneducated inventor. In one case he is probably attempting to discover something well known; in the other he lacks the education which would prevent him from attempting the hopeless task of trying to produce the impossible. Any one who studies the Patent Journal week by week must see that even to-day the attempts of a large number of inventors would be ludicrous if they were not in most cases pathetic. The truth, however, must be toldengineers in practice in the course of their work constantly spend large sums of money on inventions which, if they are more plausible, are not less impossible than those above mentioned.

Prof. Hele-Shaw has long thought that, beyond general engineering training, the time has come for an actual chair of invention. He hopes to see such a chair founded somewhere, and that a professor of invention may give lectures (one or more a year) to engineering students of different schools throughout the country. This would enable the principles on which success depends to be placed before rising engineers, as well as the methods of obtaining information on what had been already achieved in any subject, the cause of failure in previous attempts, and how to approach new problems so as to avoid falling into endless repetitions of previous workers.

\section{The Life History of the Eel.}

THE complete story of the breeding of the Johs. Schmidt in a memoir published by the Royal Society (Phil. Trans. B, vol. 2 I I, pp. I79-208, plates I7, I8, April 4, I922). The publication will become a classic of science, not only because of its literary charm and the results that it sets forth, but as a record of the resolution of a man of science determined to carry his investigation to a satisfactory conclusion.

In May I904 Dr. Schmidt, while working on fishery research on board the Danish Fishery vessel Thor west of the Faroes, found a Leptocephalus larva of $7 \frac{1}{2} \mathrm{~cm}$. in length. "With little idea, at that time, of the extraordinary difficulties " of the investigation, he began his research. From then till igro he made what use he could of the Thor, but the vessel was too small. He obtained collections made by the Michael Sars and others stored in Danish museums, but the material was very inadequate. Then he persuaded various Danish shipping companies to help, and the skippers were supplied with nets and instructions. One ship-of-war also assisted. In I9I3 a Copenhagen company allowed him the use of the Margrethe, and for five months all went well. Then the Margrethe was wrecked on a West Indian island, "but the collections fortunately were saved"! In I9I 4 and I9I 5 the United States Fishery vessel Bache and two Danish traders obtained plankton samples, and then the war stopped all further collecting till I920. Finally, a Copenhagen company gave Dr. Schmidt the use of the Dana, and with the experience gained, abundant collections were made in 1920 and I92x. It was then, "with mingled feelings," that he found that the rich material included two species of eels, the American and European. These could only be separated by laborious countings of the myotomes and pigment spots, and all this had to be done aboard ship immediately after the fishing operation.

The outcome of all these difficulties is the almost complete story of the European eel. For a period of five to twenty years, according to sex, climate, and quantity of food, the eel remains in fresh water. It is yellow-green in colour and without metallic lustre. Then the desire for food fails; the migratory instinct awakens; the silvery " bridal dress" is assumed, and the eels descend to the sea. This is the last that is seen of them, and the period of their migration is unknown. Sometime during the spring or summer, however, they spawn, in deep water, in the West Atlantic between about $22^{\circ}$ and $30^{\circ} \mathrm{N}$. lat. and $50^{\circ}$ and $65^{\circ} \mathrm{W}$. long. (roughly in the middle of the Sargasso Sea). The smallest larvæ caught are about 7 to $15 \mathrm{~mm}$. in length, and they are found at about 200 to 300 metres from the surface. From then onwards their area of distribution widens. They rise to near the surface of the sea and begin to migrate to the north-east. In the first summer they are about $25 \mathrm{~mm}$. long, and are found west of $50^{\circ} \mathrm{W}$. long. In the second summer they are 50 to $55 \mathrm{~mm}$. long, and they then inhabit the central Atlantic. In the third summer they are about $75 \mathrm{~mm}$. long, and can now be found on the European coastal banks. They are still leaf-shaped, transparent Leptocephali, but in the autumn they undergo metamorphosis and enter the rivers as the cylindrical, smoky-brown elvers, about three years in age. The further history is well known: they may ascend rivers to a height of 3000 feet above sea-level (in Switzerland). Growth proceeds, and some five to twenty years later the seaward migration occurs. The story is unique in natural history, not only for its own interest, but also because of the patience and resolution with which it has been elucidated. J. J. 